\title{
Restructuring an Emerging Market Banking Sector: The Case of Vietnam
}

\author{
Ngoc Nguyen ${ }^{1}$, Naser Ibrahim Abumustafa ${ }^{2, ~ * ~}$ \\ ${ }^{1}$ General Planning Department, Urban Infrastructure Development Investment Corporation, Hanoi, Vietnam \\ ${ }^{2}$ Department of Management Sciences \& Finance, Al-Zahra College for Women, Muscat, Oman
}

Email address:

drnaser69@hotmail.com (N. I. Abumustafa)

*Corresponding author

\section{To cite this article:}

Ngoc Nguyen, Naser Ibrahim Abumustafa. Restructuring an Emerging Market Banking Sector: The Case of Vietnam. Journal of Finance and Accounting. Vol. 5, No. 6, 2017, pp. 219-228. doi: 10.11648/j.jfa.20170506.13

Received: October 30, 2017; Accepted: November 10, 2017; Published: December 23, 2017

\begin{abstract}
This article examine whether Vietnam will be able to follow the reconstruction model developed by the Thai and South Korean banking industries in 1997, based on present-day Vietnam's similarity with those two countries in 1997. Our paper also attempts to test the efficiency of the Vietnamese Asset Management Corporation [VAMC] in the banking industry restructuring process. The article use a quantitative model to test effects of the VAMC on Vietnam's banking industry, and apply a DEA model to test the efficiency of the VAMC. The results contribute to the process of restructuring the banking industry in Vietnam, it also provide guidelines based on mathematical analysis for potential changes and improvements to both the banking industry and the bank regulatory structure in Vietnam.
\end{abstract}

Keywords: Restructuring, Emerging Markets, Banking Sector, Vietnam

\section{Introduction}

In emerging markets, particularly in developing countries, bad debts are often a serious problem. Depending on each country's specific situation and economic conditions, various markets use different methods to address bad debts to revive their economy at the macro level.

To solve problems related to bad debts, banking reform has recently begun in Vietnam. However, no official reconstruction model has yet been proven to guarantee success once implemented. Following the suggestions of Tran [2010], this paper intends to research the likelihood of success of banking industry reform in Vietnam, based on the 1997 financial restructurings of banking institutions in Thailand and South Korea. In his review of the performance of the Vietnamese banking system from 1990 to 2010, Ngo [2012] suggests that the country's performance has been worsening over time, although the size of the banking sector has been increasing.

Data

Data are drawn from official financial documents and analysis published by the Vietnamese Government, the State
Bank of Vietnam, and the Banking Department. These data will provide grounding information and support for the framework for the primary research, which consists of quantitative method using a Data Envelopment Analysis model that uses input and output variables chosen from specific financial ratios drawn from banks' financial reports.

\section{Literature Review}

Corsetti, Pesenti, and Roubini [1999] insist that the 1997 Asian financial crisis was caused by current account imbalances, by an inappropriate quantity and quality of financial 'over lending', by a general set of banking problems, and by the composition, maturity and size of capital inflows. At the end of 1996, the ratio of short-term external liabilities to foreign reserves, which is a widely used indicator of financial fragility, was more than $100 \%$ in South Korea, Indonesia, and Thailand.

After a number of failed policies, including low interest rates and hedging in both money markets and forward 
markets, Asia began to recover by seeking aid from the International Monetary Fund [IMF] in 1997 and 1998. By the summer of 1998, East Asia had sparked a devastating global turmoil, moving from emerging markets to other markets and even affecting the U.S. capital markets.

Jansen [2001] argues that the 1997 financial crisis in Thailand was a consequence, in general, of the failure of monetary policy and, in particular, of the inconsistency between the traditional policy regimes consisting of both fixed exchange rates and high interest rates and the international mobility of capital during the 1990s.

Kihwan [2006] argues that the 1997 crisis in South Korea began with rising inflation and the world economic recession. Substantial capital inflows, financial instability, and illconceived policies led to an increase in the short-term foreign currency debts held by Korean financial institutions and discouraged foreign long-term borrowing. By the end of 1997, the total short-term external debts of Korea totaled $\$ 63.8$ billion, which compared poorly to its $\$ 9.1$ billion in usable gross foreign reserves.

During the summer of 1997, a domino effect resulted when various chaebols [South Korean business conglomerates], including Kia and Hanbo, began experiencing financial difficulties. A delay in bailing out Kia raised doubts with foreign investors that the Korean government had the will and power to address the crisis effectively.

Thereafter, the government assumed responsibility for a portion of the bank debts and used public funds to rescue certain financial institutions. During the fall of 1998, the Korean Ministry of Finance and Economy devised a restructuring scheme called 'the big deals' to be implemented among major business groups, pushing chaebols into mergers and asset swaps as it attempted to increase specialization and to reap the benefits of consolidation and scale [Kim 2000].

Kim [2000] highlights three primary lessons from Korea's 1997 reform: the importance of distinguishing financial liberalization from trade liberation, the necessity of good governance in the reform process, and the need for a comprehensive scope of market reform. An effective reform strategy thus involves both changes in the policy matrix and fundamental structural changes to a wide range of social, economic, and political institutions.

Interest rates on deposits and bank spreads were the best metrics for rating banks in emerging markets. Weaker banks in Thailand and South Korea during the 1997 financial crisis were characterized by high deposit rates and low spreads.

Today, aiming to 'basically, thoroughly and comprehensively restructure the system of credit institutions, expecting local banks to achieve safe operation and sustainable performance with diversified structures of ownership, sizes, and types to be more competitive and consistent with international standards and to better meet the demand for financial and banking services of the national economy', Vietnam plans on focusing on 'improving the health and strengthening the operational capacity of credit institutions; improving their safety and operational efficiency; improving market discipline in banking operation; and striving to form at least one or two commercial banks operating on the regional scale by the end of 2015' [Nguyen and Nguyen 2012].

In recent years, following the global financial crisis of 2008, Vietnam [and the rest of Asia] has entered a period of slower growth. Every sector of the economy has encountered severe problems, including the banking sector of this middleincome country. Lower credit growth, a high non-performing loan [NPL] ratio and tighter margins indicate that the outlook for Vietnam's banking system is not as bright as it once was.

One of the most direct benefits of this scenario is that the real cost of borrowing might drop even lower, which would encourage business spending on capital goods. Another advantage is that expenditures on consumer household goods might be stimulated. Lowering interest rates would improve banks' balance sheets and their capacity to lend, which would help raise banks' net interest margin [NIMs], boosting earnings and capital. If the central bank decides to lower interest rates, asset prices will rise. As a result, an increase in the money supply will make consumers feel as if they have extra money, which will induce them to invest their excess money by buying real estate or corporate equity. [St. Louis Fed 2011]

Tong [2008] notes that there are certain signals in presentday Vietnam that might predict a crisis for its financial system that are similar to those that characterized Thailand and South Korea in 1997.

At the country level, there is a significant bad debt problem because 'a high share of non-performing assets [NPAs] threatens the liquidity and solvency of a substantial part of the banking sector' [Kawalec 2002].

There are many variables that affect the bad debt ratio significantly, including real GDP growth, the lending interest rate, the currency exchange rate and share prices. Additionally, the analysis of bad debt to accounts receivable and bad debt to sales ratios shows that bad debts have a positive correlation with realization risks in accounts receivable and with possible future write-offs.

The human factor also plays an important role, as bad debt problems might result from bad management practices, political interference, connected lending or lack of effective banking supervision [Kawalec 2002]. Of course, these serious problems do not result solely from human factors but [to some extent] from larger-scale causes such as political institutions or the involvement or manipulation of interest groups.

As a vital source of both financial and technical assistance for developing countries, the World Bank defines an emerging market according to a set of standards given by the Secretary of Agriculture. According to the World Bank list and Definition of Emerging Markets [2010], an emerging market is any country that is 'taking steps towards developing a market-oriented economy through the food, agriculture, or rural business sectors of the economy of the country; and has the potential to provide a viable and significant market for the U.S.'

The economies of China [excluding Hong Kong and 
Macau, as both are considered developed] and India are understood as the largest. The eight largest emerging and developing economies are the BRIC [Brazil, Russia, India and China] and MIKT [Mexico, Indonesia, South Korea and Turkey] countries. These countries are typically evaluated based on either nominal or inflation-adjusted GDP [The Economist 2008].

Vercueil [2012] defines an emerging economy as one with the following characteristics:

1. Intermediate income: Its PPP per capita income is between 10 and 75 percent of the average EU per capita income.

2. Catching-up growth: During (at least) the last decade, it has experienced brisk economic growth that has narrowed its income gap with advanced economies.

3. Institutional transformations and economic opening: During the same period, it has undertaken profound institutional transformations that have helped to integrate it more deeply into the world economy. Hence, emerging economies appear to be a by-product of the current rapid rate of globalization.

The governments of emerging countries have taken different measures to address the bad debt problem. Poland's attempts to solve its bad debt problem began in 1992. The Polish government decided to recapitalize its state-owned banks [SOBs] and restructure other indebted enterprises. The program covered nine banks that inherited the monobank's loan portfolios, the Savings Bank, the Bank for Agriculture, and state-owned firms in which the state held more than 50 percent of the shares. In this process, the banks were transformed into joint-stock companies - of which the sole shareholder remained the State Treasury - and would later operate as quasi-private institutions.

Established on January 26, 1998, the Indonesian Bank Restructuring Agency [IBRA], or Badan Penyehatan Perbankan Nasional [BPPN] in Indonesian, is one component of various strategic policies undertaken by the Indonesian government to cope with its banking and economic crisis, which resulted from the 1997 Asian monetary crisis. At that time, a drastic depreciation of the Indonesian rupiah [IDR] led to a strong decrease in bank liquidity and public confidence in the rupiah and the entire banking system. The situation was severe. The foreign currency debts of the nonbank private sectors reached a threshold of US\$78.1 billion in 1997, compared to the government offshore borrowing amount of US\$59.9 billion [Batunanggar 2002]. Looking back after the crisis, researchers believe that the Indonesian banking crisis was the most severe in East Asia and one of the most costly crises in the $20^{\text {th }}$ century and resulted in IDR 654 trillion of losses, i.e., an estimated 51 percent of Indonesian annual GDP. Comparing this proportion with Thailand [32.8 percent], South Korea [26.5 percent], Japan [20 percent], Malaysia [16.4 percent] and the Philippines [0.5 percent], it is easy to see how badly the crisis affected the world's largest Muslim country [Honohan and Klingebiel 2000].

The sound development of South Korea during this period led to KAMCO's choice to expand beyond the country's border. In July 2005, the South Korean National Assembly amended its legal structure to authorize KAMCO to invest in overseas NPAs. In 2008, KAMCO set up a large-scale fund with domestic pension funds and financial institutions to tap the U.S. debt markets. After scrutinizing the profitability of the U.S. market, KAMCO decided to initially make an investment of US\$500 million and has reaped considerable profit from this investment [Yonhap 2008].

During the 2007-2008 global financial crisis, KAMCO once again propped up Korea through disaster. When the crisis was at its peak, the ratio of NPLs in Korea had reached 1.11 percent of the total loans of Korean banks. Concerns were raised as the rate exceeded the warning threshold of 1 percent, which could have resulted in a serious problem. In May 2009, as a part of various measures taken to cope with the global financial crisis, the Korean government raised 40 trillion won in restructuring funds. As part of these measures, KAMCO established the Credit Recovery Fund and Restructuring Fund in 2008 and 2009. These funds have purchased 'overdue debts of 650,000 credit delinquents worth 4 trillion won and rescheduled them so that they could be paid back in installments for up to 8 years'.

The Vietnamese financial system - and particularly the banking system - has many potential risks. The process of evaluating results and supervising performances does not include functions for undertaking quantitative analysis and managing credit risks. Therefore, in this study, we intend to use a quantitative model to test the effects of the Vietnamese Asset Management Corporation [VAMC] on the Vietnamese banking industry. Data Envelopment Analysis [DEA] is the quantitative model chosen.

The Data Envelopment Analysis [DEA] model was introduced by Charnes, Cooper and Rhodes [1978] [the CCR model], based on a notion elaborated in Farrell [1957] regarding the estimation of production frontiers. The main idea of the classic DEA method is to figure out the production frontier, then use it to estimate the efficiency of production.

According to Ngo [2010], a firm, economy, or a bank is evaluated as efficient if it can maximize its outputs using a certain number of inputs. Simply put, the efficiency of production is calculated by the following equation:

\section{Efficiency $=$ Total Inputs/Total Outputs}

This ratio is always less than or equal to 1 . At 1 , the firm reaches its maximum production, in which there is no waste. The concept is to draw a line on the graph on which Input = Output, which will describe the production frontier. From there, we can measure the differences among firms' efficiencies and the production frontier.

If data from $\mathrm{N}$ companies is available, each company uses $\mathrm{X}$ inputs and $\mathrm{Y}$ outputs. With company $\mathrm{I}$, the data of inputs can be described as vector xi, and the data of outputs can be described as vector qi. Therefore, inputs and outputs of all the companies could be described by matrix $\mathrm{X}(\mathrm{N}$ rows, I columns) and matrix Q [M rows, I columns]. 
In the next step, for each company, the ratio of total inputs and total outputs $\left[\mathrm{u}^{\prime} \mathrm{q}_{\mathrm{i}} / \mathrm{v}^{\prime} \mathrm{x}_{\mathrm{i}}\right]$ are measured, in which $\mathrm{u}$ is a vector of outputs [M rows, 1 column] and $\mathrm{v}$ is a vector of inputs [ $\mathrm{N}$ rows, 1 column]. The number of maximum inputs and outputs of company i can be solved as:

$$
\begin{aligned}
& \max _{u, v}\left[u^{\prime} q_{i} / v^{\prime} x_{i}\right] \\
& \text { St: u'q } q_{j} / v^{\prime} x_{j}<=1
\end{aligned}
$$

Where $\mathrm{j}=1,2,3 \ldots \mathrm{I}$ and $\mathrm{u}, \mathrm{v}>=0$

From here, the inputs and outputs of a company are figured where its efficiency ratio is maximized while it remains less than or equal to 1 .

The method has been applied to different fields, including the banking industry.

Based on the data collected, previous findings from global research, and the current state of the banking industry in Vietnam, the next variables are used below:

1. Inputs: Fixed Assets, Labor Costs, Total Deposits

2. Outputs: Fees and Income from Interest and Loans

The DEA model has been widely used to evaluate the efficiency of different economies and banking industries. In this research, we plan to apply the DEA model to test the efficiency of the VAMC using variables from Luan, Long, and Nhut [2010] because this research is the most current study, and its methodology is reliable. However, we plan to add one more input variable into total inputs, other expenses. In this case, other expenses include advertising, PR, customer relations, and capacity. We examined the basis of the model to test the efficiency of all banks by evaluating how much input banks must use to create the same outputs. There are also 2 approaches that we want to use: operation and intermediation.

1. Operation approach: Treating banks as firms that produce banking services. Inputs are costs [interest expenses, labor costs, other expenses], while outputs are revenues [interest income, non- interest income].

2. Intermediation approach: Treating banks as financial intermediaries. Inputs are total deposits and total expenses [interest expenses plus non-interest expenses], while outputs are interest from loans and securities.

To generate the most reliable and valid results that fit the conditions of the Vietnamese banking industry, we plan to combine these two methods to result in the following

\begin{tabular}{|c|c|}
\hline Inputs & Outputs \\
\hline 1. Fixed Assets & 1. Loans and advances to customers \\
\hline 2. Deposits from customers & 2. Deposits and borrowings from other \\
\hline 3. Deposits and borrowing from other & credit institutions \\
\hline credit institutions & 3. Interest and similar income \\
\hline 4. Interest and similar expenses & 4. Fee and commission income \\
\hline 5. Salaries and related expenses & 5. Other income; net income from \\
\hline (Salaries and allowance) & investments in associates and joint- \\
\hline 6. Fee and commission expenses, & ventures \\
\hline other expenses & \\
\hline
\end{tabular}
variables:

Figure 1. Tested variables.

Data from 14 banks from 2003-2013 will be analyzed using DEAP [Data Envelopment Analysis] version 2.1, which calculates the results after data for inputs and outputs are entered. The 14 banks chosen play a majority role and make up more than 80 percent of the Vietnamese banking industry.

Based on the literature review and current available problems, the article attempt to examine these two questions:
1. What is the role of the VAMC in Vietnamese banking reform?

2. What are the impacts of interest rates and bank spreads on the performance of Vietnamese banking reform?

Hypotheses

H1: The establishment and performance of the VAMC supports the Vietnamese banking restructuring.

The time frame chosen is 2017 , as Vietnam recently began 
the reform at the end of 2012. It is likely to take at least four to five years for the reconstruction to be completed. In addition, Vietnamese banks must solve the bad-debt problem to reform successfully, which is likely to take time because of its complexity. Therefore, by the time the study is finished, the results will still be valid.

\section{Methodology}

This article consists of both primary and secondary research. The secondary research includes data from financial documents and analysis published by the World Bank, Moody's, the State Bank of Vietnam, and the Banking Department. We expect to obtain a picture of the performance of the financial and banking system in Vietnam, which will be combined with the information obtained through primary research to attain the most credible results. Primary research also consists of two parts:

A mathematical model analysis using the DEA method based on previous findings to test H1. Data were collected from the financial reports of 14 banks from 2003 to 2013. The descriptive statistics were used to interpret user input practices in the reports. Inputs include fixed assets, deposits from customers, deposits and borrowings from other credit institutions, interest and similar expenses, salaries and related expenses [salaries and allowance], fee and commission expenses, and other expenses. Outputs include: loans and advances to customers, deposits and borrowings from other credit institutions, interest and similar income, fee and commission income, other income, and net income from investments in associates and joint-ventures. Then, a quantitative model will be run based on the application of specialized software DEAP 2.1 to carry out its objectives.

\subsection{Data Analysis}

1. Method

A bank is considered as a common manufacturing enterprise that uses costs [input] to generate revenues [output]

2. Variables

1) Input [Costs]

a) Input 1: Interest expense and other related costs [The costs banks must pay to raise capital]

b) Input 2: Labor costs [salary, bonus, etc.]

c) Input 3: Other operating expenses

2) Output [Revenues]

a) Output 1: Revenue from credit operations

b) Output 2: Other income: Net income from investments in associates and joint-ventures

3. Results

1) Classification: 2 types of commercial banks

a) Group 1:5 State-owned banks [SOBs]

b) Group 2: 9 Joint-stock commercial banks [JSBs]

2) In all stated banks, the banks with higher scores than the mean are those that operate efficiently.

\begin{tabular}{|l|r|r|r|r|r|r|r|r|}
\hline & 2007 & 2008 & 2009 & 2010 & 2011 & 2012 & 2013 & Average \\
\hline CTG & 1 & 0.237 & 0.565 & 1 & 1 & 1 & 0.981 & 0.826 \\
\hline VCB & 1 & 0.282 & 0.949 & 1 & 1 & 1 & 0.902 & 0.876 \\
\hline BWD & 0.579 & 0.224 & 0.813 & 1 & 0.982 & 1 & 1 & 0.8 \\
\hline AGRB & 1 & 0.214 & 0.843 & 0.617 & 0.95 & 0.926 & 1 & 0.793 \\
\hline MHB & 0.053 & 1 & 1 & 1 & 1 & 0.965 & 1 & 0.86 \\
\hline ACB & 0.423 & 0.326 & 0.985 & 0.895 & 0.912 & 0.992 & 1 & 0.79 \\
\hline EIB & 1 & 0.454 & 1 & 1 & 1 & 1 & 1 & 0.922 \\
\hline HDB & 1 & 0.258 & 1 & 0.837 & 1 & 1 & 1 & 0.871 \\
\hline MBB & 1 & 1 & 1 & 1 & 1 & 1 & 1 & 1 \\
\hline ABB & 1 & 1 & 1 & 0.836 & 0.984 & 0.987 & 1 & 0.972 \\
\hline NAB & 1 & 1 & 0.897 & 0.779 & 0.856 & 0.96 & 1 & 0.927 \\
\hline STB & 0.24 & 1 & 0.847 & 0.898 & 1 & 0.931 & 0.944 & 0.837 \\
\hline TCB & 0.563 & 0.305 & 1 & 0.882 & 1 & 0.94 & 0.897 & 0.798 \\
\hline OCB & 1 & 0.762 & 1 & 0.528 & 0.826 & 0.692 & 1 & 0.83 \\
\hline Mean & 0.776 & 0.576 & 0.921 & 0.877 & 0.965 & 0.957 & 0.98 & 0.864 \\
\hline
\end{tabular}

Figure 2. Operation approach. Efficiency score of 14 commercial banks. 


$\begin{array}{llllll}\text { CTG } & 0.826 & \text { CTG } & 0.826 & \text { ACB } & 0.790 \\ \text { VCB } & 0.876 & \text { VCB } & 0.876 & \text { EIB } & 0.922 \\ \text { BIDV } & 0.800 & \text { BWV } & 0.800 & \text { HDB } & 0.871 \\ \text { AGRB } & 0.793 & \text { AGRB } & 0.793 & \text { MBB } & 1.000 \\ \text { MHB } & 0.860 & \text { MHB } & 0.860 & \text { ABB } & 0.972 \\ \text { ACB } & 0.790 & \text { mean } & 0.831 & \text { NAB } & 0.927 \\ \text { EIB } & 0.922 & & & \text { STB } & 0.837 \\ \text { HDB } & 0.871 & & & \text { TCB } & 0.798 \\ \text { MBB } & 1.000 & & & \text { OCB } & 0.830 \\ \text { ABB } & 0.972 & & & \text { mean } & 0.883 \\ \text { NAB } & 0.927 & & & & \\ \text { STB } & 0.837 & & & & \\ \text { TCB } & 0.798 & & & & \\ \text { OCB } & 0.830 & & & & \\ \text { mean } & 0.864 & & & & \end{array}$

Figure 3. Operation approach. A comparison of SOBs and JSBs.

1. A lower mean than the mean of the 14 stated banks indicates that the SOB's performance was below the industry average.

2. JSBs operated more efficiently than SOBs [JSBs have higher means than SOBs].

a) AGRB and OCB exhibit the lowest efficiency, but after several consecutive years, they finally achieved the highest level of efficiency and are now considered to have effective operations in 2013. This result could be due to the role of the VAMC in enhancing the operational efficiency of the banking system in 2013.

b) Notably, MBB operated efficiently at the optimum level over 7 consecutive years. MBB can later be investigated further so that its operating technique can be a role model for other banks.

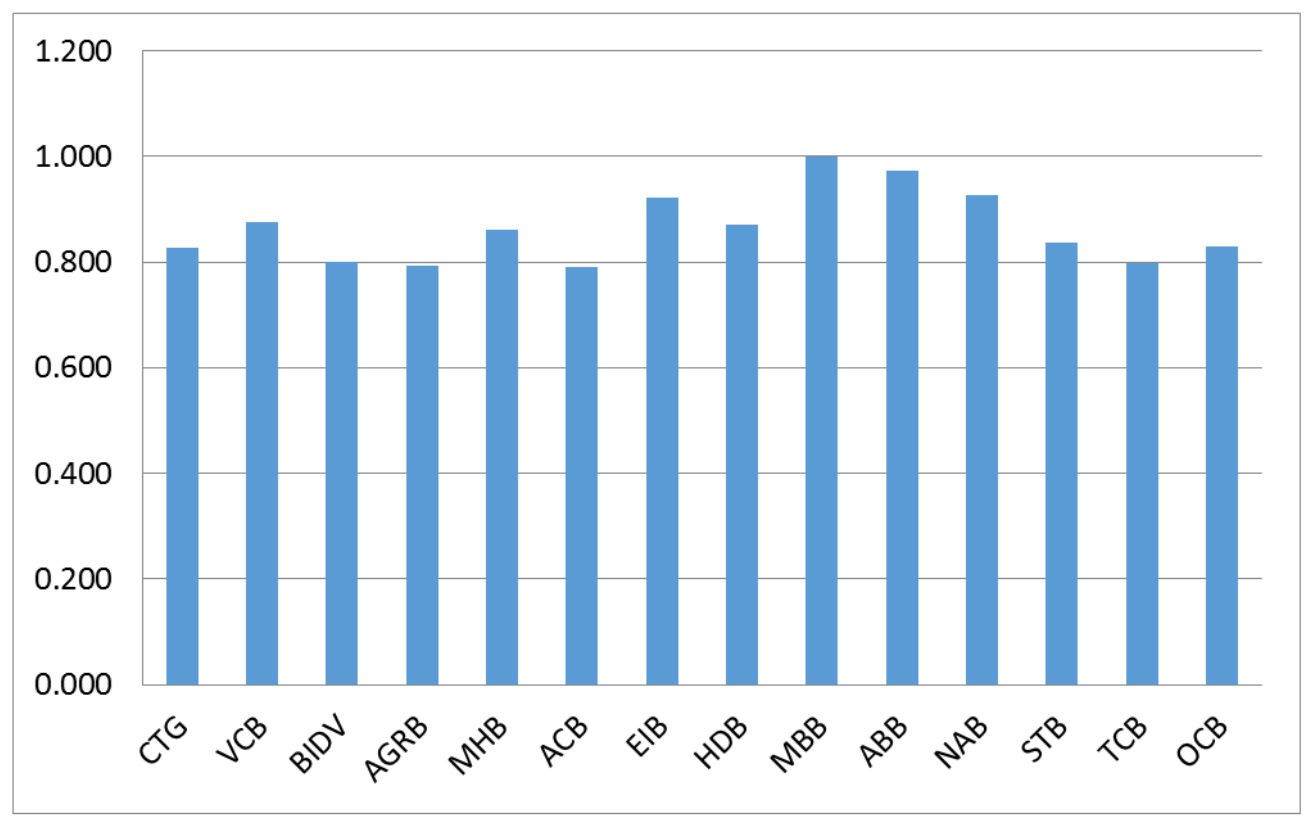

Figure 4. Operation approach. Average Performance of 14 stated Commercial Banks over the 2007-2014 Period.

JSBs are shown to be more efficient than SOBs. These JSBs have engaged in new business activities in addition to traditional activities (borrowing and lending), achieving good results.

\subsection{Intermediation Approach}

1. Method

Banks are considered to be financial intermediary institutions with characterized inputs and outputs.

2. Variables

1) Input

a) Input 1: Total deposits [total deposits of individual customers and organizational clients commercial bank's characterized input]

b) Input 2: Total costs [including labor costs, other costs - financial intermediary institution's 
characterized input]

2) Output

a) Output 1: Total loans [total loans to individual customers and organizational clients commercial bank's characterized output]

b) Output 2: Non-interest revenue [revenue from a financing activity other than loan activities]

3. Results

1) None of the stated banks achieved the optimal level of efficiency, which indicates that banks overused their sources to generate revenues in the role of financial intermediary institutions. Therefore, banks should consider cutting off some costs or finding an innovative way to achieve higher level of outputs.

2) In this case, group 2 JSBs perform under the industry average as they exhibit a lower mean than the 14 stated banks.

3) With regard to the role of financial intermediary institutions, SOBs outperformed JSBs, which indicates that SOBs are doing better at their traditional banking activities [such as lending and borrowing] because SOBs represent the government as the lender of last resort, and the government will bail out SOBs if they default. Therefore, the risk of lending money to SOBs is very low and will attract more customers than JSBs.

\begin{tabular}{|l|r|r|r|r|r|r|r|r|}
\hline & 2007 & 2008 & 2009 & 2010 & 2011 & 2012 & 2013 & Average \\
\hline CTG & 0.685 & 0.914 & 0.271 & 1 & 0.879 & 0.886 & 0.983 & 0.803 \\
\hline VCB & 0.724 & 0.906 & 1 & 0.824 & 1 & 1 & 1 & 0.922 \\
\hline BIDV & 0.794 & 1 & 0.883 & 0.969 & 1 & 1 & 1 & 0.949 \\
\hline AGRB & 0.765 & 0.863 & 1 & 1 & 0.882 & 0.99 & 0.941 & 0.92 \\
\hline MHB & 0.692 & 0.748 & 0.641 & 1 & 0.756 & 0.775 & 0.793 & 0.772 \\
\hline ACB & 0.81 & 0.846 & 0.18 & 0.778 & 0.86 & 0.846 & 0.764 & 0.726 \\
\hline EIB & 0.73 & 0.882 & 0.257 & 0.944 & 0.95 & 0.905 & 0.982 & 0.807 \\
\hline HDB & 1 & 1 & 0.256 & 0.88 & 0.593 & 0.593 & 0.549 & 0.696 \\
\hline MBB & 1 & 1 & 0.218 & 0.905 & 1 & 0.958 & 0.82 & 0.843 \\
\hline ABB & 0.714 & 0.816 & 1 & 1 & 0.741 & 0.734 & 0.675 & 0.811 \\
\hline NAB & 0.633 & 0.771 & 1 & 0.778 & 0.666 & 0.916 & 0.889 & 0.808 \\
\hline STB & 0.641 & 1 & 0.913 & 1 & 1 & 1 & 1 & 0.936 \\
\hline TCB & 0.784 & 1 & 1 & 0.784 & 0.799 & 0.754 & 0.886 & 0.858 \\
\hline OCB & 0.92 & 0.654 & 0.823 & 1 & 0.285 & 0.286 & 0.329 & 0.614 \\
\hline Mean & 0.778 & 0.886 & 0.674 & 0.919 & 0.815 & 0.832 & 0.829 & 0.819 \\
\hline
\end{tabular}

Figure 5. Intermediation approach. Efficiency score of 14 commercial banks.

$\begin{array}{llllll}\text { CTG } & 0.803 & \text { CTG } & 0.803 & \text { ACB } & 0.726 \\ \text { VCB } & 0.922 & \text { VCB } & 0.922 & \text { EIB } & 0.807 \\ \text { BIDV } & 0.949 & \text { BIDV } & 0.949 & \text { HDB } & 0.696 \\ \text { AGRB } & 0.920 & \text { AGRB } & 0.920 & \text { MBB } & 0.843 \\ \text { MHB } & 0.772 & \text { MHB } & 0.772 & \text { ABB } & 0.811 \\ \text { ACB } & 0.726 & \text { Mean } & 0.873 & \text { NAB } & 0.808 \\ \text { EIB } & 0.807 & & & \text { STB } & 0.936 \\ \text { HDB } & 0.696 & & & \text { TCB } & 0.858 \\ \text { MBB } & 0.843 & & \text { mean } & 0.614 \\ \text { ABB } & 0.811 & & & & 0.789 \\ \text { NAB } & 0.808 & & & & \\ \text { STB } & 0.936 & & & & \\ \text { TCB } & 0.858 & & & & \\ \text { OCB } & 0.614 & & & & \end{array}$

Figure 6. Intermediation approach. A comparison of SOBs and JSBS.

4) More banks are considered to be effectively operating in this model, which indicates that banks are performing better at their traditional functions as an intermediary financial institution than at some of their new adopted roles. 


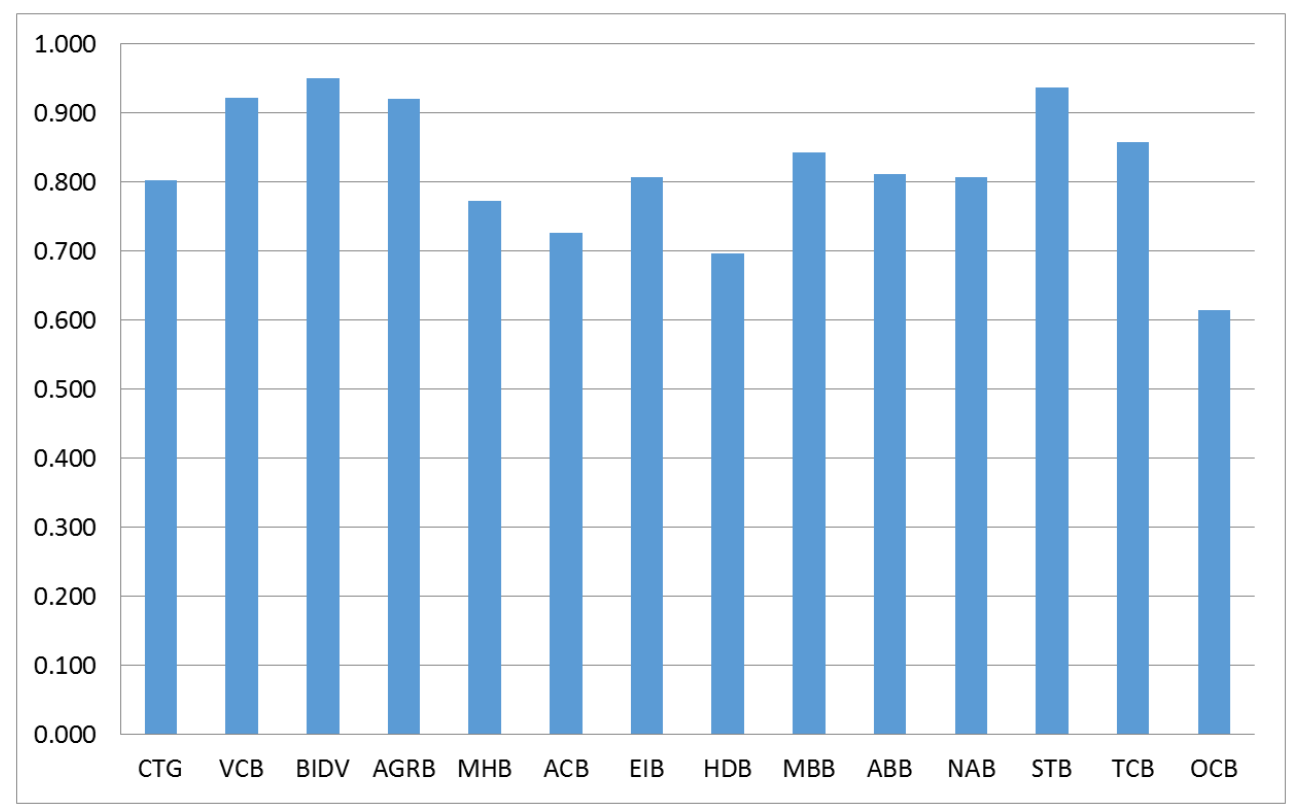

Figure 7. Intermediation approach. Average Performance of 14 stated Commercial Banks over the 2007-2014 Period.

1) Over the 7-year period, BIDV is the most efficient bank operationally, followed by VCB and AGRB.

2) It can be concluded that SOBs focus more on the key functions of a financial intermediary, and do not exert efforts into other business activities, such JSBs exert.

\subsection{Combining the Two Methods}

\begin{tabular}{|l|r|r|r|}
\hline CTG & 0.826 & 0.803 & 0.814 \\
\hline VCB & 0.876 & 0.922 & 0.899 \\
\hline BIDV & 0.800 & 0.949 & 0.875 \\
\hline AGRB & 0.793 & 0.920 & 0.857 \\
\hline MHB & 0.860 & 0.772 & 0.816 \\
\hline ACB & 0.790 & 0.726 & 0.758 \\
\hline EIB & 0.922 & 0.807 & 0.865 \\
\hline HDB & 0.871 & 0.696 & 0.783 \\
\hline MBB & 1.000 & 0.843 & 0.922 \\
\hline ABB & 0.972 & 0.811 & 0.892 \\
\hline NAB & 0.927 & 0.808 & 0.868 \\
\hline STB & 0.837 & 0.936 & 0.887 \\
\hline TCB & 0.798 & 0.858 & 0.828 \\
\hline OCB & 0.830 & 0.614 & 0.722 \\
\hline Mean & $\mathbf{0 . 8 6 4}$ & $\mathbf{0 . 8 1 9}$ & $\mathbf{0 . 8 4 2}$ \\
\hline
\end{tabular}

Figure 8. Efficiency score of 14 commercial banks. Combined operational and intermediation approach.

1) Method 1 takes into account all major activities of commercial banks.

2) Method 2 focuses on specific activities of banks as financial intermediary institutions.
3) Under method 1, more banks achieving optimal efficiency indicates that banks today are not only focusing on traditional credit operations but are also expanding their businesses to external activities such as 
financial investments and asset purchases, which are greatly developed and significantly improve the operational efficiency of banks.

4) According to both methods, OCB is the least effective bank. Thus, we can confirm that based on the model and the data, OCB must improve its methods of operation to achieve better performance in the future.

5) According to the average of the two methods, JSBs outperform - and are thus more efficient than - SOBs.

6) MBB achieves the optimal score in both methods, which indicates that based on the model and the data, MBB efficiently uses its resources to generate revenues. Future research may further investigate MBB's operational methods to examine the key to efficiency for banking activities.

7) Under Method 1, the mean efficiency score of banks in 2013 outperforms the results of all means in the 7-year range, while under Method 2, it falls into the mid-range of the results. Therefore, by combining the two methods, we conclude that the performance of the banking industry has improved in 2013; however, the results are not particularly impressive.

\section{Conclusions}

The findings of this study both contribute to the process of restructuring the banking industry in Vietnam and provide a guideline for potential changes and improvements to the Vietnamese banking industry and the regulatory scheme governing banks in the country, all based upon a mathematical analysis.

The biggest challenge to the Vietnamese banking industry, according to 38 out of 40 interviewees, is the level of bad debts in the system - which we already knew - and a new opponent, cross-ownership. We will discuss cross-ownership first. Cross-ownership in the banking system is a serious problem not only in Vietnam but also in every other country in the world. In recent years, along with a thriving banking and financial system, cross-ownership in Vietnam has become more and more complicated and harder for the government to control, thus leading to bad influences on the Vietnamese economy at the macro level.

Cross-ownership can be understood when both of two institutions own the shares of the other. It can occur as either direct or indirect cross-ownership. Direct cross-ownership occurs when firm A invests in firm B, and then - vice versa firm B invests back in firm A. The indirect form of crossownership is less transparent and harder to control. When an individual, a group of investors, or a company owns both bank A and bank B, then there is in fact a cross-ownership relation between bank $\mathrm{A}$ and bank $\mathrm{B}$, but it is indirect.

In the 2006 - 2011 period, there was sharp growth in Vietnam's banking sector in both quantity and capital. During that time, cross-ownership became relatively popular and complicated, with both positive and negative impacts on the banking system and, on a larger scale, on the macro economy of Vietnam.
Cross-ownership can be traced back to three main reasons that are described below:

1) The demand for capital increased. In the overheating period of the Vietnamese economy, commercial banks were required to boost their chartered capital to at least 3000 billion VND [approximately 140 million USD]. This regulatory change put pressure on commercial banks, forcing them to use cross-ownership to increase their 'virtual' capital in lieu of raising real money. From 2008 to 2010, some Vietnamese commercial banks successfully 'dodged' the law in this way to meet the requirements set by the State Bank of Vietnam.

2) Trust among business partners: Despite the thriving Vietnamese banking system, the level of monitoring and management has proven insufficient to gain investor trust. There are still many risks and malfunctions in both business and management in financial institutions in Vietnam, which explains why one of the most influential factors for investors remains connections. Investors can only gain trust in these institutions by virtue of involved family members or the involvement of people they know very well.

3) Firms and credit institutions aim to acquire one another to exploit economies of scale and to make it easier to lend money to their 'backyard businesses'.

Cross-ownership has characterized the Vietnamese commercial banking system for quite some time. At first, it occurred when SOBs invested in JSBs as a way to ensure the government's control over their operations. Forms of crossownership have become more complicated, however, and can be divided into these 6 groups.

The three positive groups include:

(1) State-owned commercial banks and foreign commercial banks' ownership of venture banks.

(2) Foreign strategic shareholders in commercial banks.

(3) Fund management companies as shareholders in commercial banks.

The three groups concerned include:

(1) State-owned commercial banks' ownership of JSBs.

(2) Mutual possession among JSBs.

(3) State-owned groups, corporations and individuals' ownership of JSBs.

Today, most state-owned corporations invest in credit institutions. Thus, for instance, just to name a few, Vietnam Electricity [EVN], the largest Power Company in Vietnam owns An Binh Commercial Joint-Stock Bank; Viettel Group, Vietnam's largest mobile network operator, owns the Military Commercial Joint-Stock Bank [MB]; and Vietnam National Coal - Mineral Industries Group - Vinacomin and Vietnam Rubber Group, owns Saigon-Hanoi Commercial Joint-Stock Bank [SHB].

Returning to the subject of debts, a large portion of banks in the Vietnamese market suffer from bad debts. Some analysts might think that state-owned commercial banks tend to have more NPLs than other commercial banks because of governmental influence in their loan decision process, but this is not necessarily true. Vietcombank is one of the top 
banks in terms of book value in Vietnam at the moment and it is a state-owned commercial bank. However, at the same time, other big state-owned commercial banks are in risky positions because of their underlying debts.

First and foremost, to clean up the banking system, there must be a solution for bad debts, as well as directions to lead banks to commercially suitable standards. Following this, there should be a reduction in the number of cooperating banks, and big banks should focus their activities by means of mergers and acquisitions. An expert from the Ministry of Finance [MOF] says in her responses that the MOF's strategy is to successfully execute the state-owned enterprise reform program, which will have a direct positive influence on banking industry reform by reducing NPLs because, as most commercial banks' bad debt involves state-owned enterprises. The MOF's role in the banking industry reform is to restructure state-owned enterprises, which includes financial restructurings that lead to fewer NPLs, which supports banking industry reform.

The results show some key lessons that support the restructuring process. First, cross-ownership is a cause for alarm, and its risk must be minimized as much as possible. Second, financial institutions must reduce their dependence on debt. Third, bankruptcy must be permitted and assets should be sold at market prices. Fourth, costly bureaucratic procedures should be eliminated. The Vietnamese government must also continue to liberalize its regulations, including foreign investment restrictions. These foreign investment restrictions must be reformed to facilitate foreign capital infusions. Finally, management must become more professional, developed, and better-compensated, thus eliminating nepotism and cronyism.

\section{References}

[1] Batunanggar, S. 2002. Indonesia's Banking Crisis Resolution: Lessons and the Way Forward. London: Centre for Central Banking Studies, Bank of England.

[2] Charnes, A., W. W. Cooper, and E. Rhodes. 1978. "Measuring the Efficiency of Decision Making Units." European Journal of Operational Research 2 [6]: 429-444. doi: 10.1016/03772217[78]90138-8.

[3] Corsetti, G., P. Pesenti, and N. Roubini. 1999. "What Caused the Asian Currency and Financial Crisis?" Japan and the World Economy 11 [3]: 305-373. doi: 10.1016/s09221425[99]00019-5.

[4] Denizer, C. A., M. Dinc, and M. Tarimcilar. 2000. Measuring Banking Efficiency in the Pre- and Post-Liberalization Environment: Evidence from the Turkish Banking System. Policy Research Working Paper Series 2476, The World Bank.

[5] Farrell, M. J. 1957. "The Measurement of Productive Efficiency." Journal of the Royal Statistical Society. Series A [General] 120 (3): 253-281. doi: 10.2307/2343100.

[6] Federal Reserve Bank of St. Louis [StLouisFed]. 2011. "Low Interest Rates Have Benefits And... Costs. Stlouisfed
Publications." $\quad$ Retrieved $\quad$ April 2014. https://www.stlouisfed.org/publications/itv/articles/?id=2082.

[7] Honohan, P., and D. Klingebiel. 2000. Controlling the Fiscal Costs of Banking Crises. Policy Research Working Paper Series 2441, the World Bank.

[8] Jansen, K. 2001. "Thailand, Financial Crisis and Monetary Policy." Journal of the Asia Pacific Economy 6 [1]: 124-152. doi: 10.1080/13547860020024567.

[9] Kawalec, S. 2002. "Different Models of Bad Debt Restructuring: Remark Based on Experiences with Bad Debt Problems in Developed Economies and Central European Transition Economies." In International Seminar on Comparative Experiences in Comforting Banking Sector Problems in Central/ Eastern Europe and Central Asia. Warsaw, Poland.

[10] Kihwan, K. 2006. The 1997-98 Korean Financial Crisis: Causes, Policy Response, and Lessons. Singapore: The International Monetary Fund.

[11] Kim, K. 2000. The 1997 Financial Crisis and Governance: The Case of South Korea. The Helen Kellogg Institute for International Studies, University of Notre Dame.

[12] Kvint, V. L. 2004. The Global Emerging Market in Transition: Articles, Forecasts, and Studies, 1973-2003. New York: Fordham University Press.

[13] Ngo, D.-T. 2010. Evaluating Vietnamese Commercial Banks Using Data Envelopment Analysis Approach [Vietnamese]. Hanoi: Vietnam National University working papers.

[14] Ngo, D.-T. 2012. The Performance of Vietnamese Banking System under Financial Liberalization: Measurement Using $D E A$. Hanoi: Vietnam National University working papers.

[15] Nguyen, C. M., and D. Nguyen. 2012. "Vietnam Schedule to Restructure Credit Institutions for the 2011-2015 Period." Research Paper for Mayer Brown JSM Vietnam Limited. Retrieved December 2013. http://www.martindale.com/banking-financialservices/article Mayer-Brown-JSM-VietnamLimited_1501718.htm.

[16] The Economist. 2008. "Building Brics of Growth. Economist Focus. "The Economist. Retrieved November 2013. http://www.economist.com/node/11488749.

[17] Tran, J. H. 2010. Against the Conventional Wisdom: The State- Owned Banks of Vietnam. San Francisco, Calif:: Golden Gate University.

[18] Vercueil, J. 2012. Les pays émergents. Brésil - Russie - Inde Chine... mutations économiques et nouveaux defies. [Emerging Countries. Brazil - Russia - India - China. Economic Change and New Challenges, in French]. 3rd ed. Paris: Bréal.

[19] World Bank. 2010. "World Bank List and Definition of Emerging Markets." USDA. Gov. 2013. http://www.fas.usda.gov/mos/emmarkets/World\%20Bank.pdf.

[20] Yonhap News Agency. 2008. "KAMCO to Tap U.S. Debt Markets." Yonhap News. Retrieved Nov 2013. http://english.yonhapnews.co.kr/business/2008/01/27/73/0503 000000AEN20080127002100320F.HTML. 